\title{
Siyasetin Hizmetinde Ortodoks Azizleri: \\ Orta Çağdan Modern Çağa Balkanlarda Dinsel Algılar ve Milliyetçilik
}

Selçuk Akşin Somel *

Stefan Rohdewald,

Götter der Nationen. Religiöse Erinnerungsfiguren in Serbien, Bulgarien und Makedonien bis 1944 ["Ulusların Tanrıları. 1944'e değin Sırbistan, Bulgaristan ve Makedonya'da Dinî Hatıra Şekilleri”]

Köln, Weimar, Viyana: Böhlau Verlag, 2014, 905 s., ISBN: 978-341-2222-44-4

Almanya Giessen Üniversitesi'nden Stefan Rohdewald 2014'de Balkan kültür ve siyasal tarihini yakından ilgilendiren kapsamlı bir çalısma yayınladı. Eserin odaklandığı konu geç Ortaçağ Balkan Slav topluluklarında biçimlenen dinsel suret ve sembollerin çağlar boyu süren kültürel ve siyasal "serencamları"dır. Diğer bir ifadeyle, Ortodoks suret ve sembollerin Osmanlı öncesi Bulgar ve Sırp devletlerindeki statüleri; uzun Osmanlı yüzyıllarındaki durumları; ulusal uyanışın zuhur ettiği 19. yüzyıl devresinde kazandıkları yeni anlamlar; ve son olarak Birinci Dünya Savaşı bitiminden komünist rejimlerin egemen olduğu 1944'e değin artan siyasal işlevleri bu araştırmada tetkik ediliyor. Bu yapıta göre geç Ortaçă̆ devresinde kutsanan azizler ve kutsal temaların 19. yüzyıla değin devamlılıkları oldukça cılız ve yöresel nitelikte iken milliyetçilik cereyanları dolayısıyla yeniden keşfedilerek ulus inşasında yararlanılmış, 20. yüzyılın ilk yarısındaysa siyasal açıdan otoriter, militarist ve yayılmacı gayelerle içerdikleri anlamlar aşırı ölçülerde kutsallaştırılarak çarpıtılmıştır. Ancak yazara göre söz konusu gelişmeler Balkan coğrafyasına münhasır bir vaka değildi; Batı ve Orta Avrupa’da kutsal suretler ve

* Sabancı Üniversitesi 
semboller yüzyıllar boyunca Balkanlar'da olduğu gibi siyasal amaçlarla kullanılagelmişti. Araştırmacı, eserin bitiminde Sırp ulusçuluğunun 19. yüzyıldan itibaren yücelttiği Kosova savaşı mitosunun nasıl 1980'li yıllarda vahim siyasal sonuçlara yol açtığına işaret ediyor (848-849).

$\mathrm{Bu}$ tanıtım yazısı standart kitap eleştirilerine göre daha uzun tutulmuştur. Eserin safi fiziksel hacmi ve içerdiği hayli kapsamlı bilgi hazinesi Osmanlı tarihini yakından ilgilendirmekte olup özellikle imparatorluğun dağılmasındaki temel etmenlerden birisi olan Balkan milliyetçilik akımlarının doğasına işaret etmektedir. Araştırmada ortaya konan bir çok veri ve malumatın akademik okuyucular tarafından dahi çok iyi bilinmemesinden dolayı eseri fazlaca özetlemek Osmanlı Araştırmaları okuyucusu bakımından bilgi kaybına neden olacağından ötürüdür ki tanıtımda normale göre daha fazla ayrıntı sunulmuştur.

Eserin ayrıntılı tanıtımına girişmeden önce şu gözlemi paylaşmakta yarar vardır. Günümüzün Bulgaristan’ı ve Makedonya’sındaki en saygın kamu kültür kurumları halen Aziz Kiril ve Metod kardeşler ve Ohrili Aziz Kliment gibi kilise azizlerinin adlarıyla sıfatlandırılmaktadırlar. Örneğin Bulgaristan Milli Kütüphanesi "Aziz Kiril ve Aziz Metod Ulusal Kütüphanesi", Makedonya’nın en önemli üniversitesi “Üsküp Aziz Kiril ve Aziz Metod Üniversitesi”, Tırnova üniversitesi “Tırnova Aziz Kiril ve Aziz Metod Üniversitesi” olarak adlandırılmıştır. Benzeri şekilde Bulgaristan’ın en eski üniversitesi "Sofya Üniversitesi Ohrili Aziz Kliment", Makedonya'daki Manastır üniversitesi "Ohrili Aziz Kliment Üniversitesi-Manastır” tarzında resmen isimlendirilmiştir. Oysa Rohdewald'den öğrendiğimize göre bu denli ulusal kutsiyet atfedilen söz konusu kişilikler 19. yüzyılın ikinci yarısına değin Bulgar ve Makedon halkları tarafından büyük ölçüde unutulmuş olup sonradan âdeta yeniden icat edilmiştir.

Ulusların Tanrıları çalışması "Giriş” (11-40), "Kutsal Üstatlar, Hükümdarlar ve Payitahtlar - 18. Yüzyıla Kadar Dinî Hatıra Şekilleri” (41-152), "Asyalı Boyunduruğunun Üstesinden Gelmek İçin Uzun 19. Yüzyılda Avrupalı, Hıristiyan Ulusların İcat Edilişi”" (153-448), "Dinî Hatıralar Aracılığıyla Milletin Seferber Edilerek Kutsallaştırılması (1918-1944)” (473-798), "Bitiş” (799-849) başlıklı beş ana bölümden oluşmakta, aradaki 449-472 sayfalarda konuyla ilgili görseller sunulmaktadır. Eserin "Giriş" bölümünde tarihyazımsal bağlam, araştırma sorunsalları, mevcut literatür ve kaynak durumu hakkında bilgi veriliyor. Burada yazarın önemsediği sorunsallar arasında "dinsel belleğin siyasal egemenlik işleviyle veya kolektif, hatta ulusal aidiyet tasarımıyla olan içrek bağı ve bu çerçevede 
dinî hatıralara yüklenilen siyasal veya ulusal anlamlar"ın incelenmesi (12), "Ortaçağ dinsel anılarındaki tarihsel çağlar ve kilit şahsiyetlerin Osmanlı bağlamının çözülüşü sürecinde milliyetçi bir formata dönüşerek yeniden hatırlanmasının iç mantığı" (12) ve "Ortodoks Güney Slavlarının hatıra mekânları ve bunların etkileşim süreçlerinin tetkik edilmesi suretiyle birbiriyle yakından ilintili Sırp, Bulgar ve Makedon kimlik tasarımları arasındaki bağlantıların netleştirilmesi” (20) gibi hususlar bulunuyor. Söz konusu sorunsalların analizinde Rohdewald, Maurice Halbwachs ve Jan Assmann gibi kolektif ve kültürel bellek sosyologlarından esinlenmekle birlikte Halbwachs ve Assmann'da sergilenen statik modeller yerine dinamik tarihsel süreçler içerisinde hatıraların değişimini irdelemektedir, ki bu anlamda eserin kolektif bellek araştırmalarına özgün bir katkı sunduğunu söyleyebiliriz (23-26). Aynı şekilde bu eser, Yakın Çağ Avrupa tarihi ve ulusçuluk akımlarının modernleşme olgusuyla güçlenmesi problematiği çerçevesinde Ortodoks kültürler ve modernleşme süreçlerinin kavranmasına dair şimdiye değin var olan literatür boşluğunu önemli ölçüde dolduracak niteliktedir (35-36). Sorun şudur ki Osmanlı İmparatorluğu bünyesinde yüzyıllarca kurumsallığını sürdürmüş bir millet-i Rum’un 19. yüzyıl sonlarında kristalize olacak Balkan ulusal Ortodoks kiliselerine tedricen dönüşümü süreci halen teferruatıyla tetkik edilmiş değildir (37).

Eserin ikinci bölümü niteliğindeki "Kutsal Üstatlar, Hükümdarlar ve Payitahtlar - 18. Yüzyıla Kadar Dinî Hatıra Şekilleri” (41-152) faslında Kiril ve Metod gibi terbiyeci ve öğretmenler, Ohrili Kliment ve Naum gibi âlimler, koruyucu azizler ve keramet sahipleri, kutsiyet atfedilen belirli Bulgar ve Sırp hükümdarları ve hanedanları, Rilalı Yuvan, Azize Petka, Yuvakım, Gavril, Pohor gibi tekil bazı kutsal şahsiyetler, ayrıca da bir kutsiyet motifi olarak Kosova Meydan Muharebesi'nin Erken Modern Çağ Güney Slav halkları arasındaki algılarının nasıl evrimleştiği irdeleniyor. Bölümün başında vurgulandığı üzere 19. yüzyıl öncesinde Rumeli Slav nüfusunun ezici çoğunluğu kırsal kesimde yaşamakta olup kentsel Hıristiyan nüfus ağırlıklı olarak etnik Rumlardan oluşmaktaydı. Bu şartlarda Güney Slavlardaki Ortodoks inancı Hıristiyanlık öncesi yerel geleneklerle içiçe haldeydi. Üstelik Osmanlı siyasi ve toplumsal düzeni bağlamında kilise kurumları ulusal nitelikte olmayıp etniküstü karakterdeydi. Bu koşullarda 19. yüzyılın ikinci yarısından itibaren Sırp ve Bulgar aydınlarının iddia ettiği gibi Kiril ve Method, Ohrili Kliment, Aziz Sava vb. Ortaçağ aziz figürlerinin gerçekte ne ölçüde yüzyıllar boyunca Bulgar ve Sırp milletlerinin orijinal özünü korumada rol oynadığı yazar tarafından sorgulanıyor (42-43). 
Rohdewald'ın belirttiği üzere eldeki tarihi verilere göre 9. yüzyılda Selânik'te doğmuş olan Kiril ve Metod biraderler Slav değil, daha ziyade etnik Rum sayılmaları gerekir. Papalığın hizmetinde misyonerlik yapmış olan bu kardeşler Slav kavimleri arasında da faaliyet göstermelerine karşın çağdaş kayıtlar özel olarak bir Bulgar veya Sırp topluluğunu zikretmiyor. Ölümlerinden kısa bir sonra azizlik mertebesine yükselen Kiril ve Metod gerek Bizans gerekse Roma tarafından kutsanmış olup herhangi bir etnisiteyle özel bağları yoktu (43-48). Ancak 12. yüzyıldan sonra bu birader azizlerin hususan "Slav alfabesini icat ettikleri" ve Bulgarları hak yoluna soktukları ilk defa Bizanslı yazarlarca iddia edilmiştir. Rohdewald'e göre burada Bizanslılar ve kendilerine bağımlı komşu Slav halkları arasında kültürlerarası bir iletişim hali söz konusuydu. 13. yüzyılda Dördüncü Haçlı Seferi bağlamında Bulgar Çarlı̆̆ı ihya edildiğinde Romàya yakınlaşma siyaseti çerçevesinde Tırnova piskoposu Kiril ve Metod'un Bulgarları aydınlattığını öne sürmüş, kısa bir süre sonra başka bir kaynak bu aziz kardeşlerin doğrudan Bulgar olduklarını iddia etmiştir. Bulgar Çarlığı kardeşlerin Bulgarlığı iddiasını esas olarak hükümdarları güçlendirmek amaçlı kullanmış, ancak Kiril ve Metod'a gösterilen ihtiram az sayıda seçkinle sınırlı kalmıştır. Zira bu kardeşler Balkanlar dışında vefat etmişlerdi; ayrıca bu azizlere ithaf edilmiş ne bir kilise, ne de bir manastır vardı. Osmanlı egemenliği zamanında Kiril ve Metod ne Bulgar keşişleri ne de Bulgar köylüsü tarafından anılmaktaydı (43-55). Buna karşın birader azizler Sokollu Mehmed Paşa’nın yeniden tesis ettirdiği Sırp İpek Patrikhanesi'nde 1560'dan sonra yortularda kayda değer şekilde zikredilmeye başlanmış, 17. ve 18 . yüzyıl Sırp ruhban sınıfı tarafından ibadetlerde anılmıştır (56-58).

Slav veya Yunan kökenli olup olmadığı bilinmeyen Ohrili Kliment gençliğinde Kiril'in yanında misyonerlik çalışmalarında bulunmuş, Roma’da ruhban sınıfına dahil olmuş ve Bulgar hanı Boris tarafından Makedonyaya Hıristiyanlı̆̆ı yaymak üzere gönderilmiştir. Kiril ve Metod'dan farklı olarak Ohri'de vefat edip yerel bir manastıra defnedildiğinden bölgedeki Slav halk kendisini evliya olarak benimsemiş, hakkında keramet iddiaları yayılmıştır. Kabir ve manastırın bulunduğu Ohri 1000 civarında bir Bulgar başpiskoposluğu mertebesini kazanmış, bu çerçevede kemikleri insanlara şifa veren Aziz Kliment yöre halkının kolektif belleğine yerleşmiştir. İsmen "Bulgar" olmasına karşın gerçekte Ekümenik Patrikhane'ye bağlı olan Ohri başpiskoposluğu Rum ruhban sınıfının Balkan Slavları üzerindeki dinî egemenliğinin bir manivelasıydı. Ohri başpiskoposluğuyla adı özdeşleşmiş olmasına rağmen Aziz Kliment kültü Bulgarların ötesinde Rum, Sırp, Arnavut ve diğer Hıristiyan toplulukları da kapsamış olup dar 
anlamda etnik nitelikli değildi. Bu durum Osmanlı döneminde de değişmemişti. Üstelik Kliment'in öğrencilerinden Aziz Naum, Makedonya ve Arnavutluk coğrafyasında sadece Ortodokslarca değil, bölgedeki Bektaşi Arnavutlar tarafından “Sarı Saltuk” hüviyetiyle kutsanıyordu (60-68).

Osmanlı öncesi Balkan krallıklarında din adamlarının yanısıra Bizans geleneğine uygun olarak hükümdarlara ve hanedanlara da azizlik mertebesi bahşedilmek suretiyle kraliyet rejimlerine manevi temeller oluşturulduğunu bu eserden öğrenmekteyiz. Örneğin vaftizle Mikail adını alan Bulgar hanı Boris öldükten sonra gerek Ortodokslar, gerekse Roma tarafından aziz ilan edilmişti. Torunu Çar Petır da azizlik mertebesine erişmişti. Hükümdarlık gücünü pekiştirmek amacıyla esasında siyasetle alakasız Rilalı Yuvan veya Azize Petka gibi münzevi bazı kutsal şahsiyetler de ilâveten devreye sokuluyordu. Rila dağında inzivaya çekilen keşiş Yuvan (ö. 946) çilekeşliği dolayısıyla o denli saygınlık kazanmıştı ki hem sağlığında ayağına gelen Çar Petır'ın iktidarına, hem de vefatından sonra mezarını ziyaret eden Bizans imparatoru Manuel Komnenos'un egemenliğine meşruiyet kaynağı teşkil edebilmişti. 1183'de Balkanları talan eden Macarlar keşiş Yuvan'ın nâşını beraberlerinde götürmüşler, ama Yuvan'ın sergilediği keramet üzerine kemikler korkuyla karışık ihtiramla iade edilmişti. Macarların Katolikliği çerçevesinde Rilalı Yuvan kültünün Ortodoksları aşarak Katoliklere de teşmil olması dolayısıyla burada bir "çoklu kültürel temas alanı" olgusu yazar tarafından saptanmaktadır. İkinci Bulgar devleti kurulduktan sonra bu sefer Çar Yuvan Asen 1196'da yeni payitaht Tırnova'ya Rilalı Yuvan'ın kemiklerini getirtmişti. Bulgar siyasal varlığının son bulması sonrasında II. Murad'ın eşlerinden Sırp prensesi Mara Despina Hatun (Brankoviç) 1469'da Aziz Yuvan'ın nâşını Rila’ya taşıtmış ve Rila manastırını Sırp keşişlerine onartmıştır. Bu suretle önceleri Bulgar nüfuzu altındaki bu önemli manastır ve Aziz Yuvan kültü şimdi Sırp etkisi altına girmiştir (70-92).

Buna benzer hadiseler 11. yüzyıl başlarında Konstantinopolis’te ölmüş Azize Petka bağlamında da ortaya çıkmışı. Sağlığında Bulgarlıkla alakasız bir Rum azizesi olan Petka 13. ve 14. yüzyıllarda Bulgar çarlarınca kutsanmış olup Balkanlarda Osmanlı fütuhatı üzerine nâşı önce Tırnova'dan Vidin'e, sonra yine Mara Hatun tarafından Belgrad'a nakledilmiştir. Böylelikle Azize Petka Sırp siyasi bağlamına dahil olmuştur. 1521'de Belgrad fethedildiğinde kemikler orijinal mekânı olan İstanbul'a geri getirilmiş, ama 1641'de bu sefer Boğdan'da Yaş'a taşınmıştır. Nâşları sıkça yer değiştiren Aziz Yuvan ve Azize Petka Macaristan'dan Yunanistan'a 
uzanan geniş coğrafyada yüzyıllar boyunca hatırlanmış, hatta Azize Petka Müslüman Arnavutlarca Cuma namazlarında zikredilmiştir (80-83).

Tüm bir hanedana kutsiyet atfetmek suretiyle hükümdarlara azizlik bahşetmek uygulaması Sırp Nemanya sülalesi örneğinde dikkati çekmektedir. Buna göre hanedanın kurucusu Stefan Nemanya (ö. 1199) Tanrı tarafından Sırbistan’ı yönetmek üzere hükümdarlığa atanmıştı. Yaşlılığında hükümdarlığı bırakıp Aynaroz’a çekilerek Simeon adını alan Stefan'ın oğullarından Rastko (ö.1236), Aziz Sava adıyla Sırbistan'ın koruyucu azizi olarak kabul edilmiştir. Bilahare Aziz Simeon'un kemikleri Sırplarca kutsal kabul edilen Studenica manastırına getirilmiş, böylelikle Sırbistan'da bir Simeon kültü zuhur etmiştir. Aziz Simeon hatırası kilise çevrelerinde 17. yüzyıla değin beslenirken oğlu Aziz Sava, "vatanımızın [manevî] yenileyicisi” sıfatıyla yeni bir Balkan kült nesnesine dönüşmüştür. Daha önceleri Hıristiyanlığı yayan ve Sırpların koruyucu evliyası olarak anılan Savàya artan Osmanlı tehdidi karşısında 14. yüzyıldan itibaren Sırbistan vatanını muzaffer kılması için niyaz edilir olmuştur. Sava’nın bir kült nesnesi olan kemiklerinin 1594 Sırp-Bulgar ayaklanması esnasında Sadrazam Koca Sinan Paşa tarafından Belgrad'da yakılması sonrasında babası Aziz Simeon kültü yeniden canlandırılmıştır. 19. yüzyıl öncesinde İpek Sırp Ortodoks Patrikhanesi tarafından beslenen Aziz Sava ve Aziz Simeon kültleri dar anlamda etnik Sırplara değil, benzeri bir kültten yoksun Bulgar köylülüğüne de hitap etmekteydi. Yazara göre komşu Katolik Habsburg İmparatorluğunun söz konusu kültleri zaman zaman koruması altına alması hadisenin dar anlamda Ortodoksluğun ötesine geçtiğini göstermekteydi (95-135).

Eserin ikinci bölümünde yer alan dikkate değer diğer bir 19. yüzyıl öncesi hatıra şekli Kosova Meydan Muharebesi, Prens Lazar ve Aziz Vitus Günü çerçevesinde irdelenmektedir. Öğrendiğimize göre savaştan henüz otuz yıl geçmeden Kosova muharebesi, Lazar ve onunla birlikte ölmüş savaşçllara dair en az on kutsal kilise metni oluşmuştu bile. 1398'den önce yazılmış bir dinî destanda Lazar ve yanında çarpışıp ölen tüm Ortodoks muharipler aziz ilan edilmiş olup Lazar, kutsallığı tescil edilmiş Nemanya hanedanına dahil edilmişti. Daha ilginç olanı, destanın muharebenin Sava ve Simeon'un manevî güçleri sayesinde Hıristiyanlar için parlak bir zaferle sonuçlanarak padişah Murat'ın ve pek çok düşmanın kılıçtan geçirildiğini öne sürmesidir. Daha sonraki metinlerde Lazar ve savaşçları Hz. İsa’nın çarmıha gerilişi gibi âdeta kendilerini din için feda etmiş azizler olarak betimlenirken Lazar'ın "cennet krallığına" eriştiği anlatılmaktadır. Nâşı 
Ravanica manastırında bulunan Lazar etrafında oluşturulan bu kült söz konusu manastır ruhban camiasınca beslenmekteyken 1690'da Avusturya ordusunun Osmanlılar karşısında mağlubiyeti üzerine aniden kesintiye uğramış, ricat eden Avusturya birlikleri ve yerel destekçileriyle beraber manastır keşişleri de Tuna’nın öte yakasına geçmişler, Lazar'ın kemiklerini de beraberlerinde Macaristan’a, Fruşka Gora'ya taşımışlardır. Öte yandan Lazar konulu dinî türküler Balkan Slavları arasında yüzyıllarca sürmüştü; bu halk türkülerinde âdeta Hz. İsa’nın çarmıha gerilişi öncesindeki son yemekte olduğu üzere Lazar'ın muharebe öncesi son akşam yemeğinde şehadete ereceğinin içine doğduğu, İlyas Peygamber kendisine görünüp "yeryüzü krallığı” yerine "cennet krallığı”nı tercih etmesini sağladığı betimlenmektedir. Türkülerin bazılarındaysa Lazar’’n Sırplık için öldüğü ve Lazar ile birlikte savaşmayan Sırpların "şerefsiz" oldukları ilan ediliyordu. Buna karşın yazar, bütün bu 19. yüzyll öncesi Lazar kültünde herhangi bir şekilde "intikam" çağrısı yapılmadığını saptıyor (135-152).

Rohdewald'ın çalışmasının "Asyalı Boyunduruğunun Üstesinden Gelmek İçin Uzun 19. Yüzyılda Avrupalı, Hıristiyan Ulusların İcat Edilişi” başlıklı üçüncü bölümünde (153-448) ilk olarak Batı Avrupa kökenli ulusçuluk akımlarının Balkanlara girişine, 19. yüzyıl Rumeli coğrafyasında eğitimli bir Bulgar tüccar sınıfının ortaya çıkışına, Tanzimat reformları ve Sırbistan ve Bulgaristan devletlerinin kuruluşu sürecinde ulusal Ortodoks kiliselerinin gelişimine değinilmekte. Bu noktada Rohdewald, yüzyıllar boyu devam ettiği iddia edilen "Türk boyunduruğu” süresince Bulgar ruhban sınıfının Bulgar ulusal bilincini muhafaza ettiğine dair söylemin ancak 1872 'den sonra geçmişi yüceltici hatıra kültürüyle birlikte ortaya çıktığını vurguluyor. Öte yandan yeni kurulan Sırbistan ve Bulgaristan devletleri özünde laik çizgide olup ruhban sınıfını mümkün mertebe hizada tutmaya çalışmışlardır. Bulgarlar arasında ulusal bilinç sorununu derinleştiren husus bağımsızlık öncesinde Bulgar elitleri arasında Osmanlı Devleti ve padişahına sadakat tutumunun yaygın olmasıydı. Bütün bu parametreler çerçevesinde üçüncü bölümün ana problematiği, yeniden gündeme getirilip modernleşme uğruna anlamları değiştirilen dinî hatıra şekillerinin gerek Osmanlı reform çağı bağlamında ve gerekse bağımsızlıklarını kazandıklarında Ortodoks Güney Slavların toplumsal ve siyasal modernleşme tasarımları açısından ne ölçüde belirleyici nitelikte olduğu meselesidir (153-160).

İlk etapta yazar Aziz Sava kültünün Sırbistan ve Osmanlı Makedonyası'nda yeniden yükselişini ele alıyor (160-214). Buna göre Sava kültü 18. yüzyılın ikinci 
yarısında Tuna’nın kuzey yakasındaki Sırplar arasında Avusturya yönetimince diğer azizlere kıyasla siyasi açıdan en zararsız telakki edilerek teşvik edilmiştir. Burada amaç Sırp tarihinde varolan birçok hükümdar azizlerin anısını bastırmak suretiyle olası bir ulusal hak talebinin önüne geçmekti. Önceleri Sırp mümin ve papazları bu politikaya tepki gösterseler de söz konusu yaklaşım Osmanlı Sırpları arasında da yayılarak sonuçta Sırp elitleri arasında herhangi bir ulusal bilinç ortaya çıkmadan önce bir "koruyucu aziz" temayüz etmiş oldu. Habsburg Sırpları arasında özellikle bir "maarif evliyası" olarak revaç bulan Sava'ya 1827'de Sırbistan Beyliği tarafından bir resmî bayram günü tahsis edilmiş ve bu aziz için okullarda dersler konmuştur. Beylik, sözü geçen evliyayı Batılılaşma siyasetinin bir parçası olarak köylülük arasında devlete ve yasalara saygıyı güçlendirerek bir yurttaşlık duygusunu geliştirmek üzere araçsallaştırmıştır. Burada yazar ilginç bir biçimde seküler ve Aydınlanmacı bir siyasi kültürü teşvik amacıyla Aziz Sava gibi dinî bir figür kullanıldığını tespit etmektedir. Sırbistan egemenliğini kazandıktan sonra 1886 'da Aziz Sava Cemiyeti mezkûr kültü toplumun tüm kesimlerine yaymak üzere faaliyete geçmiş, 1890 sonrasında Sırp Ortodoks Kilisesi de Aziz Sava kültünü desteklemek hususunda kendini âdeta mecbur hissetmiştir. Artan milliyetçilik atmosferinde, özellikle Balkan Savaşları ve sonrasında Aziz Sava’ya ayrıca militarist, savaşçı bir kimlik yakıştırılmıştır. Bu cemiyet Sırp irredantizmine hizmet amacıyla Osmanlı Kosova, Manastır ve Selanik vilayetlerinde Sırp okullarının açılmasına önayak olmuştur.

15. yüzyıldan itibaren Mara Hatun dolayısıyla Sırp kültür dünyasına ihraç edildiğini gördüğümüz Rilalı Aziz Yuvan, Bulgar tarihyazımının kurucusu Paisiy Hilendarski tarafından 1762'de “Aziz İvan” şekliyle Bulgar ulusuna maledilmiştir. Amaç Bulgarlara bir ulusal evliya ve böylelikle bir ulusal gelenek ve kimlik kazandırmaktı. Ne var ki Bulgar nüfusu arasında okuryazarlığın neredeyse yok seviyesinde olması nedeniyle Bulgar aydınlarının neşriyatlarına karşın 19. yüzyılın ikinci yarısına değin Rilalı Aziz İvan halk arasında yankı bulmamıştır. Ancak 1860 sonrasında Aziz İvan ve o bağlamda Rila manastırı Bulgar ulusal uyanışının bir milli mabedi niteliğini kazanmaya başlamıştır. Aziz Sava örneğinde de görüldüğü üzere Aziz İvan Tanzimat devri Bulgar mekteplerinde bir "maarif evliyası" hüviyetiyle Bulgar çocuklarına ve gazeteler yoluyla okur-yazar kesime tanıtılmıştır. Rila manastırının Bulgar seküler aydınlarının aksine Aziz İvan’ı dünyevi bir ulusal evliya sıfatıyla sahip çıkmayışı ruhban kesiminden bir çoğunun muhtemelen Osmanlı bünyesinde kalmayı tercih etmelerinde yatmaktaydı. Bundan dolayıdır ki Bulgar Ortodoks Kilisesi Bulgaristan Prensliği kurulduktan epeyce zaman sonra, 
yani ancak 1895 'ten başlayarak Aziz İvan'a ciddi anlamda sahip çıkmış ve 1905 'de kiliselerde adına ayinler düzenlenmiştir (214-233).

Güney Slavları açısından en önemli azizlerden Kiril ve Metod biraderlere baktığımızda Modern Çağ Bulgar, Sırp ve diğer Slav milliyetçilerinin bu kardeşleri aralarında paylaşamadıklarını görmekteyiz (233-343). Diğer azizlerden ayrı olarak kemikleri Balkan haricinde kaldığından herhangi bir yerel halk kültünün ortaya çıkmadığı Kiril ve Metod ancak Aydınlanmacı zihniyetli milliyetçi yazarlar tarafından birer ulusal evliya olarak gündeme getirilmişlerdir. 19. yüzyıl ortalarına değin Bulgar ve Sırp yazarlar Kiril ve Metod'u aziz olmaktan ziyade birer terbiyeci ve öğretmen sıfatıyla zikrederlerken yüzyılın ikinci yarısından başlayarak Çek, Slovak, Rus aydınları Panslavist akım bağlamında bu kardeşleri yüceltmişlerdir. Az sayıda bazı yazarlar haricinde Kiril ve Metod isimleri Balkanlarda Ortaçağdan beri tümüyle unutulmuş olduğundan ancak Üsküp ve Filibe'deki Bulgar okullarında 1850 ’lerde başlayan Kiril ve Metod anma günleriyle bu kutsal kişiler giderek tanınmaya başlamış, Bulgar ruhban kesimi ise biraderleri Rum Ekümenik Patrikhane egemenliğinden kurtuluş sürecinde araçsallaştırmıştır. 1860'ların sonlarına gelindiğinde birader azizler artık Bulgar dil, din ve ulusal kimliğinin kaynağı sıfatıyla âdeta tanrısal bir konuma getirilmekteydiler. Dahası, kardeşlerden Kiril'e Bulgar ulusal haklarının yılmaz savaşçısı sıfatı yapıştırılarak dünya tarihi içerisinde Bulgar tarihine meşruiyet ve ağırlık kazandırılmaya çalışılıyordu. 1878'de Bulgaristan Prensliği vücuda geldiğinde Kiril ve Metod Bulgarların Avrupalı ve uygar bir ulus olduklarını, dolayısıyla varolma hakkına sahip olduklarını ispata yarayacak postkolonyal birer araca dönüşmüşlerdi. Bu süreci kurumsallaştırmak üzere, daha önceden Sırbistan'da kurulan Aziz Sava Cemiyeti'ne benzer biçimde 1891'de Sofya’da Aziz Kiril ve Aziz Metod Cemiyeti oluşturulmuştur. Sırplar ve özellikle Katolik Hırvatlar ise 19. yüzyıl ortalarından başlayarak Kiril ve Metod'u bir Güney Slav birliğinin uygarlaştırıcı sembol karakterleri olarak yüceltmeye başlamışlar, bu arada kardeşlere sahip çıkmak için kendi aralarında rekabete girmişlerdir. Osmanlı Rumelisi'ndeki bazı Makedon aydınlar da birader azizlerin "Selanikli Bulgar" olduğunu iddia etmişlerdir. 20. yüzyıla girildiğinde, özellikle de Balkan ve Birinci Dünya Savaşları ortamında Kiril ve Metod isimleri hem Bulgarlar hem de Sırplar tarafından militarist amaçlarla ve Makedonya'daki yayılmacı emellerini meşrulaştırmak gayesiyle kötüye kullanılmıştır.

Bir diğer aziz, Ohrili Kliment, 18. yüzyılda Paisiy Hilendarski tarafından önemi altı çizilerek vurgulansa bile 19. yüzyıl sonlarına değin Bulgarların genelinin 
dikkatini çekmemiştir. İlk defa Kliment'e ihtiram doğrultusunda çabalar Ohri ve Struga çevresinde kurulan Bulgar okulları dolayısıyla yöre halkının talepleriyle, 1859 'dan itibaren ortaya çıkmıştır. Böylelikle Rohdewald'e göre Kliment figürü Makedonya yöre Slav ahalisinin kendini "Bulgar" olarak tanımlama olanağını sağlamaktaydı. Esasında yöre Türklerinin Kliment’i "Babalık" adıyla saygı göstermeleri dolayısıyla Makedonya Slavları da Kliment'e "Babalăk" diyordu. 1880'lerde Makedonya'da ortaya çıkan Slav komitacıları şiddet içeren ihtilalci andlarını Ohrili Aziz Kliment adına içmeye başlamışlardı. Bulgaristan Prensliği'nde ise Aziz Kliment'in tanınması 20. yüzyılın başlarını, Bulgaristan Kilisesi’nin tanıtım çabalarını beklemiştir. Ancak Balkan Savaşları sonrasında Aziz Kliment doğrudan Bulgaristan Krallığı'nın resmî söylemlerine dahil edilmiştir. Bu bağlamda Kliment "Bulgar ulusunun kendine özgünlüğünün simgesi", "Bulgar dehası" olarak nitelendirililir olmuştur (343-375).

Eserin bu bölümünde yeniden canlandırma süreçlerini gördüğümüz tarihî hatıra şekilleri içerisinde belki de en ayrıksı olanı Kosova Meydan Muharebesi, Prens Lazar ve Aziz Vitus Günü'nün bir ulusal mitosa dönüştürülmesi olgusudur. Rohdewald'e göre modern Sırp tarih yazımının nüvesi 1765 'te ortaya çıktığında tarihçi Pavle Yulinaç ne Kosova Savaşı'na herhangi bir kutsiyet atfetmiş, ne de Lazar’a dinsel sıfatlar yüklemişti. Ancak 19. yüzyılın ilk yarısından başlayarak Kosova vakası ve Aziz Vitus Günü esas olarak Tuna kuzeyinde yaşayan Habsburg Sırplarının ürettiği edebi eserlerde dramatize edilir olmuş, yine buradaki Sırp rahipler konuya dinsel bir renk vermeye başlamışlardı. Buna karşın 1851'de Belgrad'da Sırbistan Beyliği memurları Lazar'ı anma toplantısı düzenlediğinde Belgrad'da görevli Osmanlı komutanının baskısıyla toplantının düzenleyicisi şehir dışına sürülmüştü. 1869'dan itibaren ruhban kesimi Aziz Vitus gününü dinî bir anma günü, Lazar’ı bir din şehidi olarak kabul etmeye başladı. Böylelikle Kosova Meydan Muharebesi, Lazar ve Aziz Vitus günü kutsiyet kazandı. Sırbistan egemen bir krallı̆̆a dönüştükten sonra 1889'da Kosova savaşının 500. yıldönümü çeşitli törenlerle anıldı; bu arada kraliyet rejimi söz konusu törenleri siyasal meşruiyetini temellendirmek üzere araçsallaştırdı. Giderek Kosova Meydan Muharebesi'ne daha fazla yüklenen kutsallık başlı başına Sırp ulusuna atfedilen bir kutsallığa dönüşür oldu (375-391).

Üçüncü bölümün konusu olan tarihî hatıra şekillerinin yeniden canlandırılması sürecinde karşımıza çıkan son örnek Ortaçă̆ Sırp ve Bulgar hükümdarlarının kutsallaştırılması ve dinî-ulusal belleğe dayalı mekân tasarımlarıdır (391-448). 
Modern Çağda Sırpların Nemanya hanedanını ilk kez zikreden kişi Bulgar tarihçisi Paisiy Hilendarski olmakla beraber sülalenin Latin kökenli olduğunu iddia etmiş ve Sırpların hükümdarlarına azizlik atfetmelerini eleştirmiştir. Rohdewald'a göre burada bir Bulgar aydınının Sırp tarihsel kişiliklerinin itibarlarını azaltmak suretiyle Sırpların Slavlar içerisindeki tarihsel anı ve nüfuzlarını zedeleme çabası söz konusuydu. Buna rağmen 1804'de Sırp isyanı patlak verdiğinde ruhban kesimi asi halkın iradesini Nemanya hanedanının yeniden canlanışı olarak yorumlayarak göklere çıkardı. Öte yandan Nemanya hanedanının Tuna kuzeyindeki laik Sırp yazarlarca 19. yüzyılın ilk yarısında genelde dünyevî bir biçimde tasvir edildiği görülüyordu. Ancak 1882'de Sırp prensi kendini kral ilan etmesiyle Sırbistan devleti kraliyet rejimini meşrulaştırmak üzere Nemanya hanedanına ulusal kutsiyet atfetmeye başlamıştır. Bundan sonra tarih ders kitaplarında Sırp büyükleri arasında Aziz Sava’nın yanısıra Nemanyalılar da yer alır oldu (391-407).

Tarihsel Bulgar hükümdarlarına baktığımızda ise Paisiy'in Sırp hükümdarlarına yaptığının aksine Ortaçağ Bulgar hanlarına abartılı bir önem bahşettiğini görmekteyiz. Öte yandan 1794-95'de Sırp papaz tarihçi Yuvan Rayiç vaftiz olmuş ilk han olan Boris’i önemle zikretmiştir. Tanzimat devri Bulgar aydınlarının bakış açısından Boris bir kilise kurucusu olup esas olarak dünyevî bir hükümdardı. Ancak Sırbistan'da da olduğu üzere özerk Bulgaristan hükümeti de monarşik rejimi meşrulaştırmak kaygısıyla Boris’i ululamaya başlamıştır. Boris’in bir ulusal aziz mertebesine erişmesi 1900 sonrasında gerek kilise gerekse laik aydınlarca Bulgar milliyetçiliğinin Osmanlılara, Yunanlılara ve Sırplara karşı bilenmesi sürecinde gerçekleşmiştir. Tüm bu gelişmelere koşut olarak hem Sırplar hem de Bulgarlar Ortaçağdan kalma manastır mekânlarının ulusal ve manevî değerini coğrafik tasavvurlarına ve irredantist emellerine hizmet edecek biçimde abartmışlardır (407448).

Rohdewald, eserinin can alıcı kısmı olarak "Dinî Hatıralar Aracılığıyla Milletin Seferber Edilerek Kutsallaştırılması (1918-1944)” bölümünü (473-798) görüyor. Zaten çalışmanın fiziksel hacminin yaklaşık yarısını söz konusu dördüncü bölüm teşkil etmekte. Burada Birinci Dünya Savaşı ertesinde siyasal krizlerle boğuşan parlamenter sistemler ve iktisadi buhranlar bağlamında Balkanlarda kraliyet rejimlerinin otoriterleşerek aşırı milliyetçiliğin liberal modernleşme tasavvurlarını reddetmesi sürecinde 19. yüzyılda canlandırılmış tarihî hatıra şekillerinin bu devrede hangi suretlerle araçsallaştırıldığı ele alınıyor. İki savaş arası devrede bir yandan eğitimin yaygınlık kazanması ve kitle iletişim araçlarının devreye 
girmesi, öte yandan kilisenin yeni koşullara ayak uydurması sonucunda tarihî hatıra şekillerinin siyasi kullanımı yeni boyutlar kazanmıştır.

Örneğin Kosova Muharebesi ve Aziz Vitus Günü hatıra şekli 1918'de henüz yeni kurulmuş olup Sırpların egemen olduğu Yugoslavya Krallığı'nda (1929 öncesinde Sırp, Hırvat ve Sloven Krallığı) Nikola Velimiroviç gibi din adamlarınca "Tanrı'nın izniyle" Güney Slavlarının gelecekteki ulusal zaferlerinin bir müjdecisi olarak yorumlanmış, Kosova ovası Sırpların en kutsal mabedi, Sırpların Kudüs'ü ilan edilmiştir. Ona göre Hıristiyan dünyasının kapılarına dayanan başka ırk ve inançlı kabilelere karşı Sırplar bekçilik yapmış ve yaptıkları fedakârlıklarla Avrupa’nın ilerlemesini sağlamışlardır. Velimiroviç’in geliştirdiği bu yeni söylem çerçevesinde mezkûr hatıra şekli Yugoslavya'nın Kosova bölgesini ilhakını meşrulaştırıcı bir araca dönüştürülmüştür. Aziz Vitus Günü Belgrad'ın ötesinde, Saraybosna ve Üsküp gibi merkezlerde gerek okullarda, gerekse kitlesel spor gösterileriyle anılmaya başlanmıştır (475-512).

Aynı şekilde Aziz Sava kültü, ortak bir Yugoslav kimliği yaratmak üzere seferber edilmiş, ancak Ortodoks kimliği baskılanarak daha ziyade dünyevî erdemleri ön plana çıkarılmıştır. Amaç dinlerüstü bir hatıra şekli geliştirmek olup Boşnakların bir kısmında başarılı da olmuştur. Ne var ki Aziz Sava kültünün esas şekillenişi 1930’lardan başlayarak ilahiyat öğrencileri ve yine Ortodoks ruhban eliyle olmuş, "Aziz Savacilık" (Svetosavlje) adıyla bir ideoloji öne sürülerek Slav etnisitesiyle H1ristiyanlığın sentezlendiği, Sırp halk ruhunu aksettirecek örnek bir "Slav insanı" yaratılması gündeme gelmiştir. Bir Hitler hayranı olan Piskopos Velimiroviç bir "ulusal önder" sıfatıyla Aziz Sava’yı Hitler ile kıyaslayabilmiştir (512-572).

İki savaş arası devrede Ohrili Aziz Kliment'in Bulgaristan Krallığı'nca sahip çıkılması komşusu Yugoslavya ile sorunlara neden olacak nitelikteydi (572-610). 1918 sonrasında dahi henüz yerel Makedonya azizi olmak hüviyetini aşamamış olan Kliment esas olarak Sofyadaki Makedon göçmen topluluğu tarafindan 1srarla Bulgar hükümetine hatırlatılıyordu. Makedonya’nın Bulgaristan tarafından Yugoslavya işgali altında bir "kayıp yavru vatan" gözüyle bakılması Aziz Kliment’i Sofya açısından Makedonya üzerinde hak iddiasını meşrulaştırıcı bir tarihsel hatıra şekli niteliğini kazandırıyordu. Bu bağlamda Aziz Kliment'in bir Bulgar olduğu ve ayrıca "milliyetin en iyi koruyucusunun Bulgar dili olduğu" görüşünü bir manevî miras olarak bıraktığı iddia edilmeye başlandı. Rohdewald'e göre 1930'lara gelindiğinde artık bir zamanların yerel koruyucu azizi ve gariban hastaları sağaltarak keramet sergileyen Kliment yerini nüfusun homojenizasyonu ve 
yayılmacılık siyasetini meşrulaştırarak kutsiyet veren bir Kliment'e bırakmıştı. 1941'de Nazi Almanyası Yugoslavya’ya saldırdığında Bulgaristan bu gelişmeyi fırsat bilerek Makedonya’yı ilhak etmiş, bunu yaparken de Aziz Kliment' in "manevî birleştirici” olduğu ileri sürülmüştür.

Selânikli biraderlere gelecek olursak, Aziz Kiril ve Aziz Metod 1918 sonrasında hem Yugoslavya'da, hem de Bulgaristan'da özel bayramlarla anılmışlardır (610-704). Ancak 1920’lerin Yugoslavyası'ndaki anma günleri Aziz Sava için düzenlenenlere kıyasla hayli sönük olup kilise ayinleriyle sınırlı kalmıştır. Dönemin Yugoslavya’sı bu kardeşlere spesifik bir Sırplık veya Bulgarlık atfetmek yerine umumen Slavlığa ve Hıristiyanlığa hizmetleri vurgulanmakta ve çokuluslu Yugoslavya'yı birleştirici, özellikle de Makedonya'yı entegre edici bir araç olarak kabul etmekteydi. Birçok Yugoslav yazarı Kiril ve Metod'un etnik olarak Rum veya Bizanslı olarak kabul etmekten çekinmemiştir (610-629).

Savaş sonrası Bulgaristanı'na bakıldığında Selânikli biraderlerin Slavlığa hizmetleri vurgulanmakla beraber konu esas olarak Bulgar ulusu merkezli olarak ele alınmıştır. Bulgaristan, savaş mağlubu İttifak blokunun bir parçası olarak kendisine empoze edilen Neuilly Antlaşması dolayısıyla Yugoslavya, Romanya ve Yunanistan'a toprak terkine zorlanmıştı. Bu durum Bulgar kamuoyunda derin bir infiale neden olarak 1920'lerin başlarında Bulgar halkının silkinip yeniden canlanması bağlamında Kiril ve Metod'un uygarlaştırıcı ışığı bir irşat kaynağı olarak vurgulanmış, yabancı ve düşman Batı modalarına karşı Selânikli kardeşlerin birleştirici manevî değerlerine dönülmesi çağrıları yapılmıştır. 1935 sonrasında söylem sertleşerek birader azizler "irksal ve kültürel özgürlüğün” sağlanması için gerekli olan siyasi iradeye örnek gösterilmişlerdir. Ohrili Aziz Kliment örneğinde olduğu gibi Bulgaristan 1941'de Makedonya'yı işgal ettiğinde Kiril ve Metod kardeşlere militarist bir kimlik atfedilerek Bulgar saldırganlığına meşruiyet atfedilmiştir (629-704).

Artık Bulgarlaşmış şekliyle Rilalı Aziz "İvan”a bakacak olursak (704-734), söz konusu azizin resmî bir tatil günüyle anılması 1922 yılında, bir dil olarak Bulgarcanın muhafaza edilişini ve Bulgarların kültürel uyanışını yad etmek amacıyla konmuş, sonra "Emeği Geçmiş Bulgarlar Bayramı" adını almıştır. Ancak Rilalı İvan kısa zamanda Batı ve liberalizm düşmanı kilise çevreleri, özellikle de Arşimandrit Dr. Evtimiy tarafından Bulgarları uyandırıp kültürel ve manevî özlerine döndürme gayesi doğrultusunda bayraklaştırılmaya başlamıştır. Bu bağlamda o ana değin kimsenin ilgilenmediği ve uğramadığı Rila manastırı keşfedilerek 1935 
sonrasında âdeta bir ulusal hac merkezine dönüştürülmüştür. İkinci Dünya Savaşı yaklaştı̆̆ında Aziz İvan halkı silahlandırmak üzere seferber etmek amacıyla devreye sokulmuş, 1941'den sonra ise ilhak edilen Makedonya'nın her ne pahasına olursa olsun elde tutulması çağrılarında ana figür olarak ön plana çıkmıştır.

Dördüncü bölümün son kısmı (734-798) Orta ve Yakın Çağlarda Bulgar ve Sırp hükümdarlarına ulusal kutsiyet atfedilme siyasetini irdeliyor. Rohdewald'ın da gösterdiği üzere bu siyaset zaman zaman Bulgarlarla Sırplar arasında rekabet yaratabiliyordu. 1918'de tahta çıkmış olan Bulgar kralı III. Boris, Bulgar hanı Aziz Boris’i gerek kendi meşruiyetini güçlendirmek, gerekse Makedonya Slavları üzerinde nüfuzunu güçlendirmek gayesiyle araçsallaşıtırdığında Üsküp'de Sırp rahibi Ljub. Mitroviç Bulgar hanı Boris’in gerçekte kafası traş edilmişs sarıklı bir Müslüman olduğu konusunda yayınlara girişmişti. III. Boris 1943'de öldüğünde nâşı Sırp Nemanya hanedanı taklit edilircesine bir azize benzer şekilde Rila manastırına defnedilmiştir. Yugoslavya’nın Sırp kökenli Karayorgiyeviç hanedanından Kral Petar 1921'de öldüğ̈̈nde Belgrad basını kendisini "Kosova’nın intikamcısı", "birleşik halkın ilk kralı", "Tanrı’nın yönlendirmesiyle Musa misali halkını arz-1 mev'uda götürmüş önder” başlıklarıyla ulu bir aziz ilan etmişti. Petar'ın halefi Aleksandar'ın nikâh töreni dolayısıyla Sırbistan Ortodoks Kilisesi yayınladığı beyanda genç kralı "Tanrı'nın yardımına mazhar bir hükümdar" olarak nitelendirmiş olup ülkenin ulusal tarihini Tanrı, hanedan ve Kosova mitosuyla bütünleştirmişti. Aleksandar 1934'de resmî ziyarette bulunduğu Fransa’nın Marsilya şehrinde suikaste kurban gittiğinde kendisi "şehit kral", "Kumanova kahramanı ve Kosova’nın intikamcısı" ilan edilmiş, kilisenin yetkili ağzı Piskopos Velimiroviç Aleksandar'ı Nemanya hanedanı ve Aziz Sava’nın manevî mirasçısı olarak duyurmuştu. Rohdewald, tüm bu hükümdar kutsama siyasetine ilave olarak aynı zaman devresinde birer ülke olarak Bulgaristan, Sırbistan ve Makedonya'nın kendi başlarına birer dinî ve ulusal hatıra mekânı şeklinde algılandıklarını da saptamaktadır.

Eserin sonuç kısmına geldiğimizde Rohdewald tarihsel kopmalar ve süreklilikler sorununa değiniyor. Kendisinin de tespit ettiği üzere Ortaçağda zuhur etmiş olan belirli tarihî ve dinî hatıra şekilleri Erken Modern, 19. yüzyıl ve Yakın Çağlarda farklı nitelikli siyasal ve dinsel-klerikal sadakat ilişkilerini tahkim etmek veya sonraları gelişen ulusal aidiyetleri pekiştirmek üzere tekrar tekrar karşımıza çıkmıştır. Yazar, söz konusu çarpıcı durumu Braudel'ci anlamıyla bir la longue durée ("uzun erimli zaman”) vakası olarak değerlendirmektedir. Kendi içerisinde 
ciddî kopmalar barındırmasına karşın özünde bambaşka işlevlerle ve son derece değişik toplumsal ve iletişimsel koşullar dâhilinde habire tekerrür eden mezkûr tarihî ve dinî hatıra şekilleri Rohdewald'e göre ancak bellek söyleminin yapısalcı tarihi çerçevesinde kavranabilir. Öte yandan yazarın da vurguladığı üzere Ortaçağdan kalma dinî hatıra şekillerinin Modern Çağda kitle iletişim araçları ve örgün eğitim yoluyla bu sefer ulus devlet inşası projesine seferber edilmesi "geleneğin icadı", hatta yüzyıllar boyu tekerrür hadisesi göz önünde tutulursa belki "geleneğin icadı geleneği" olarak da nitelendirilebilir. Dikkate alınması gereken bir diğer husus çok dinli ve çok etnili, halkın önemli ölçüde içiçe yaşadığı bir Osmanlı Balkan dünyasında spesifik tarihî ve dinî hatıra şekillerinin ısrarla canlandırılmasının arkasında milliyetçi aktörlerin tahayyül ettikleri ulusu biçimlendirme gayretinin yatması ve bu amaçla sembol bazlı ayrımcılık uyguladıkları gerçeğidir. Esasında dinî hatıra şekillerinden bazılarının Katolikler ve hatta Müslümanlarca da paylaşıldığı düşünülecek olursa bahis konusu sembollerin geleneksel bağlamından koparılarak neden yeniden tanımlanmak suretiyle "geleneğin yeniden icat edildiği” daha iyi anlaşılabilir. Son olarak, 1918 sonrasında Balkan ülkeleri tüm bu tarihî ve dinî hatıra şekillerini iç ve dış siyasette antiliberal ve yayılmacı politikaları uğruna araçsallaştırmışlar ve söz konusu süreci meşrulaştırıcı bir ulusal tarih yazımı oluşturmuşlardır (842-846).

Eserin yazımında Bulgarca, Sırpça, Makedonca, Yunanca kadim el yazmalarından 20. yüzyıl sinematografik malzemelerine değin neredeyse her tür birincil kaynaktan yararlanılmıştır. Aynı şey büyük ölçüde ikincil literatür için de söz konusudur. Bu yapıta dair bazı eleştirel gözlemlerde bulunmak gerekirse öncelikle 19. yüzyıl Balkanları ve ulusçuluk akımları bağlamında 1878 öncesi Babıâli politikalarını günümüzde bile oldukça iyi ortaya koyan H.İnalcık'n Tanzimat ve Bulgar Meselesi, R. Davison'un Reform in the Ottoman Empire veya Yonca Köksal'ın yayınlarının dikkate alınmamasının eserde yarattığı bariz bilgi boşluklarıdır. Eserin arka planında bir Osmanlı varlığı seziliyor, ama bir aktör olarak Osmanlı yönetimi neredeyse yok konumundadır. Bir diğer sorun, yazarın Bulgar ve Sırp kaynaklarına yeterli eleştirel mesafe koyamaması sonucunda ortaya çıkan bazı maddi hatalardır. Örneğin Bulgar ulusal tarih yazımının kahramanlaştırarak başlıca reformların öncüsü olarak sunduğu Midhat Paşa söz konusu abartılmış şekliyle esere de yansımıştır. Yine muhtemelen Bulgar kaynaklarına dayanarak Midhat Paşa bir Pomak olarak sunulmuştur, ki o dönemlerde Arnavutluk, Bosna-Hersek ve Rodoplar gibi etnik bakımdan nispeten homojen coğrafyalar hariç Balkan Müslümanlarının etnik kimliğini güvenilir şekilde saptamak neredeyse 
olanaksızdır (154). Bulgar ulusal tarih bakış açısının eserin içeriğine çarpıcı bir yansıması imparatorluk merkezi İstanbul'un - ki esasen Balkan coğrafyasının doğu ucudur - bir "diaspora" olarak nitelendirilmesidir. Halbuki 1878 öncesinde İstanbul Bulgar nüfusunun önemli bir kısmının yoğunlaştığı bir kültür merkeziydi (248). Aynı durum Sırp kaynakları açısından da varittir. Kosova Muharebesi'nin 500 yıldönümü anma töreninin 1889 yılında, yani Abdülhamid rejimi devrinde, Sırp kralı, hükümeti ve patriği eşliğinde Osmanlı toprakları dâhilindeki Kosova ovasında gerçekleştirildiği doğrultusundaki Sırp milliyetçi propaganda kurgusunun Rohdewald tarafından sorgulanmaksızın olduğu gibi esere aktarıldığ görülmekte (381). Bir başka örnek Panslavist bir gençlik ve spor örgütlenmesi olan Sokol ("Doğan") teşkilatları irdelenirken dikkati çekiyor. Buna göre 1925'de Belgrad'da Aziz Vitus Günü anmaları için Polonya, Çekoslovakya ve Rusyadan Sokol temsilcileri gelerek şehir merkezinde bayraklarıyla resmî geçit düzenlemişlerdi. Sorun şu ki o zamanın Sovyet rejimi 1923'de Rus Sokol teşkilatı üyelerini gerici, milliyetçi ve burjuva ideolojisini teşvik edici oldukları gerekçesiyle tutuklamış ve örgüt yasaklanmıştı. Dolayısıyla "Rusya"dan Sokol temsilcilerinin gelmesi fiziksel açıdan olanaksızdı (490). Daha ikincil bir hata olarak Khalki Ruhban Akademisi'ni Heybeliada yerine Rodos yakınlarında bir adaya yerleştirilmesi zikredilebilir (217). Eleştiriler bir tarafa bırakılacak olursa Rohdewald'in bu eserinin bin yılı aşan uzun zaman dilimi süresince belirli bir coğrafyadaki farklı siyasal ve toplumsal birimlerin paylaştığı ortak dinî ve tarihî hatıra şekillerinin evrimleşme sürecinin bir karşılaştırmalı araştırmasını ortaya koyması bakımından kültür tarihi sahasında muhtemelen bir "ilk"i teşkil ettiğini söylemek abartı olmayacaktır. 